Transportation Research Forum

National Culture and Competitive Strategy Disclosure in Global Airline Strategic Alliances Author(s): Catherine Giapponi and Carl Scheraga

Source: Journal of the Transportation Research Forum, Vol. 47, No. 1 (Spring 2008), pp. 57-72

Published by: Transportation Research Forum

Stable URL: http://www.trforum.org/journal

The Transportation Research Forum, founded in 1958, is an independent, nonprofit organization of transportation professionals who conduct, use, and benefit from research. Its purpose is to provide an impartial meeting ground for carriers, shippers, government officials, consultants, university researchers, suppliers, and others seeking exchange of information and ideas related to both passenger and freight transportation. More information on the Transportation Research Forum can be found on the Web at www.trforum.org. 


\title{
National Culture and Competitive Strategy Disclosure in Global Airline Strategic Alliances
}

\author{
by Catherine Giapponi and Carl Scheraga
}

Corporate transparency, which involves financial, governance, and competitive strategy disclosure, may have implications with respect to the development and effectiveness of alliance systems. This study investigates the intensity of competitive strategy disclosure, which has received little attention in the literature by the members of the three major airline alliances, Star, oneworld, and SkyTeam. Through an examination of the corporate annual reports of each participant, the level of strategy disclosure is assessed. Further, based on the seminal work of Gray (1988) that explored the relationship between a country's cultural profile and the level of disclosure by corporations in that country, the study investigates the relationship between the intensity of disclosure and the cultural identity of each of the airline alliance members.

\section{INTRODUCTION}

Strategic alliances have become an increasingly important part of the corporate strategic planning process in the global airline industry. The 1990s witnessed the emergence of three global multicarrier alliances - Star, oneworld, and SkyTeam. These three alliances are comprised of airlines spanning numerous national cultures and geographic regions. This study examines the existing literature on competitive strategy disclosure. While governance and financial disclosure have been intensively investigated, the same is not true with regard to disclosure of firms' competitive strategies. In this paper, this phenomenon is investigated within the context of the above mentioned global airline strategic alliances. Drawing on existing literature, we provide a motivation for suggesting that there is an important need for competitive strategy transparency in such alliances. Additionally, previous empirical work suggests that national culture does indeed affect the level of transparency in firms' competitive strategy. Thus, this study does two things. It measures the level of competitive strategy transparency within the three global airline alliances. Additionally, it empirically investigates whether, in the context of these alliances, national culture significantly affects the level of competitive strategy transparency. In fact, this study does find a statistically significant relationship in this regard. If, as noted below, global airline strategic alliances have yet to move beyond the initial phase of development, this empirical result highlights a managerial issue that will be of continuing importance with regard to the growth and success of these alliances.

Michael Porter in his work The Competitive Advantage of Nations (1990, 66-67) ominously notes that "alliances are frequently transitional devices." They may often be a temporary managerial reaction in industries undergoing structural change or escalating competition. Doganis (2001) has argued that there are three phases to building strategic alliances in the global airline industry, such that, these partnerships achieve a sense of long-term commitment on the part of alliance participants. The first of these phases is primarily oriented toward generating additional revenues through the mechanisms of network expansion and joint marketing. The second phase is focused on cost savings. This may entail separate agreements between strategic alliance partners in specific areas where joint operations can reduce costs. The final or third phase is characterized by the partners commingling their assets and using them jointly. There will be the movement away from separate brand identities to the emphasis and adoption of a single alliance brand.

A Boston Consulting Group study by Cools and Roos (2005) suggests that global airline strategic alliances have not moved beyond the first of the phases described by Doganis (2001). The study notes that alliances in this industry developed as a strategic alternative to merger and 
acquisition strategies that were prohibited by regulatory and cultural barriers. Excess capacity and poor economic performance moved the airline industry to pursue strategic alliances that would provide opportunities similar to those associated with consolidation, including: operational synergies, the reduction of costs, improved asset utilization, and platforms for future growth. Airline alliances have provided consumers with benefits that include improved connectivity and increased flight frequency, as well as the consolidation of frequent flyer programs. Cools and Roos $(2005,18)$ go on to emphasize, however, that the extra revenue that has resulted from these consumer benefits has been almost fully realized or "harvested." It is noted that the alliances have not been as effective in achieving difficult cost synergies. The study identifies four barriers that inhibit the facilitation of more extensive synergies. One impediment is an asymmetry of benefits that accrue to the airlines that make the initial investments necessary to generate the cost synergies. Perceived inequity in financial return on such investments will reduce an alliance partner's willingness to invest in such programs. In addition, not all alliance members will have the necessary competencies to realize the full benefits. The irreversibility of investments necessary for a commitment to an alliance is another barrier noted in the study. A third barrier is the perception that a significant engagement in a strategic alliance erodes future potential options, both financial and managerial, as it reduces the partner's ability to pursue alternative opportunities. Finally, cumbersome decision-making and alliance governance issues complicate the development of more extensive operational relationships. To this latter point, often every airline in an alliance has an equal vote, regardless of size or importance. Thus, operational consolidations have typically been bilateral in nature, involving only two members of an alliance, rather than all members.

Doganis (2001) suggests that for global airline strategic alliances to move from phase one to phase three, there must be a sharing of long-term vision and objectives by all the alliance partners. The vision and objectives of an alliance must be communicated to and understood by each level of personnel in the participant airlines. Additionally, clear, neutral but strong strategic alliance governance must be in place.

Given the importance of a shared understanding of vision and objectives, strategic transparency, as influenced by national culture, is an important factor to consider in the identification of barriers that inhibit the evolution of airline alliance systems beyond phase one. This study examines the issue of strategic transparency and disclosure in the context of the three major global strategic alliances in the airline industry. As noted above, while these alliances have been successful in achieving incremental revenue enhancements, they have been less so with regard to the achievement of economic synergies. Santema and van Oijen $(2005,354)$ define strategy disclosure as “...the revelation of information an organization decides to share with its stakeholders on the strategy it is pursuing and going to pursue in the future." The current study explores the extent of such "revelation" or the intensity of competitive strategy disclosure by the members of the three major global airline alliances. The framework used in this research for measuring the transparency in a firm's competitive strategy is an adaptation of a model developed by Santema and van Oijen (2005). This framework rests on a foundation that allows for an understanding of the organizational drivers of these economic synergies, specifically those associated with competitive strategy transparency. Competitive strategy transparency is investigated by the examination of corporate annual reports. The 2005 annual reports of all the members of the three major airline alliances - Star, oneworld, and SkyTeam - are utilized. There is, as detailed below, analytical precedent for this approach.

As noted above, the three alliances are comprised of airlines that span numerous national cultures. The seminal work by Gray (1988) and subsequent research has demonstrated a relationship between a country's cultural profile as measured by Hofstede's (1980) dimensions and the level of disclosure in the annual corporate reports of firms in that country. Thus, this study investigates not only the level of competitive strategy transparency demonstrated by participants in each of the three major airline alliances but the relationship between said transparency and the cultural identity of each of the participants. 


\section{COMPETITIVE STRATEGY DISCLOSURE}

The focus of the theoretical and academic literature on transparency has been on the concept of corporate transparency. The manner is which this concept has been defined in empirical studies is typified by the framework of Bushman et al. (2004). This framework has five components: financial disclosures, governance disclosures, accounting principles, timeliness of disclosures, and credibility of disclosures. Financial disclosure includes information on business segment performance, R\&D and capital expenditures, accounting policies, and subsidiary operations. Governance disclosure encompasses information on major shareholders, management, boards of directors, director and officer remuneration, and director and officer shareholdings. Accounting principles relate to information on consolidation and discretionary reserves or balance sheet accounts representing temporary accumulations of earnings from the current year or recent past, while timeliness of disclosures captures the frequency of reporting, the consolidation of interim reports, and the number of disclosed items. The credibility of disclosures is the percentage of information audited by the Big 5 accounting firms in a country (Bushman et al. 2004).

Not surprisingly, this framework for defining corporate transparency is reflected in the corporate governance indices that have been developed to measure transparency (see Doidge et al. forthcoming). The Standard \& Poor's (S\&P) governance transparency index includes variables drawn from the three broad categories of ownership structure and investor rights, financial transparency and information disclosure, and board and management structure and processes (Standard \& Poors 2004). The governance ratings of Credit Lyonnais Securities Asia (CLSA) construct a composite index from variables reflecting the seven categories of management discipline, transparency, independence, accountability, responsibility, fairness, and social responsibility (Credit Lyonnais Securities Asia 2001). Transparency is measured in a manner that is almost identical to the model of Bushman et al. (2004) noted above. Finally, governance ratings constructed by the FTSE Group and Institutional Shareholder Services (ISS) utilize criteria in the eight categories of board, audit, charter/bylaws, anti-takeover provisions, executive and director compensation, qualitative factors, ownership, and director education (Institutional Shareholder Services 2003). The CLSA ratings cover emerging and newly-emerged countries. The S\&P and ISS ratings cover both developed and emerging countries.

Giapponi and Scheraga (2007) examined the issue of governance disclosure on the part of global airlines in each of the three major alliances. They utilized an extended variable set that built upon the original five variables utilized by Bushman et al. (2004) in their definition of the transparency sub-category of governance disclosure. Because airline strategic alliances span an array of national cultures which influence the development of such relationships, they also examined the impact of national culture as a determinant of governance transparency. A significant finding of this study is that national culture impacts corporate governance disclosure in the airline industry thus highlighting the importance of understanding the role cultural factors play in corporate transparency as it impacts the evolving relationships in the airline alliance networks.

Although governance and financial disclosure have been studied extensively, there appears to be a dearth of empirical work that examines those aspects of corporate transparency that focus specifically on the competitive strategy of the firm. A study by Meek et al. (1995) examined some aspects of strategy disclosure as part of a larger research study of voluntary disclosure and was limited to companies in U.S., U.K., and Continental Europe. More focused strategy disclosure research was conducted by Santema and van de Rijt (2001), but the study involved only Dutch companies. Santema and van Oijen (2005) extended the research of strategic transparency in their examination of firms across multiple industries in five European countries. Unlike these studies, which are limited in global reach, our research in the global airline industry affords the opportunity to examine competitive strategic disclosure across a much larger number of countries and cultures. 


\section{GLOBAL AIRLINE STRATEGIC ALLIANCES AND THE NEED FOR TRANSPARENCY IN STRATEGY}

Porter (1980) provides a comprehensive discussion of the elements of a competitive strategy. A firm's competitive strategy is articulated through two key elements. The first is the firm's goals which provide a broad definition of how it defines its basis for competing and its specific economic and non-economic objectives. The second is the operating policies through which the firm seeks to achieve these goals. In formulating its competitive strategy, a firm must consider its internal strengths and weaknesses, broad macro environmental and industry specific opportunities and threats, the personal values of the organization, and broader societal expectations.

The above discussion suggests a strong need for transparency in competitive strategies between strategic alliance partners. It was noted above that Porter (1980) defined two key elements that comprised a firm's competitive strategy. The first was a clear articulation of a firm's goals and objectives. Specific to strategic alliances, Whipple and Frankel (2000) suggest that clear goals and the ability to meet performance expectations are important factors influencing the success of alliances relationships. Other important factors include trust, senior management support, and partner compatibility (Whipple and Frankel 2000). It has been argued that different alliance partners may have different views on trust and what it entails (Koza and Levin 1998; Whipple and Frankel 2000). If mutual trust is best fostered when the structure of an alliance closely supports the intent of the alliance, then alliances must be carefully planned and controlled so that trust and defined boundaries are not violated (Spekman et al. 1998; Whippel and Frankel 2000). Critical to the formation of an alliance is agreement on the expected contribution of each participant and the allocation of profits. Such agreement is not always easily reached because every firm has its own unique objectives that it wishes to achieve (Lewis 1990). It is important, therefore, that each alliance member has a clear understanding of what it must invest in the strategic alliance and what the alliance member can expect in return. Such understanding implies a need for strategic transparency.

The studies just noted generally focus on partner and relationship characteristics in strategic alliances. A study by Saxton (1997) observes that similarity in organizational processes is desirable for the promotion of cooperation in strategic alliances. Thus, the potential for a positive outcome in a strategic alliance is enhanced by the reputation of alliance partners, the existence of a prior relationship between partners, shared decision-making, and similarities between partners.

However, the need for transparency in strategic alliance partners' competitive strategies also arises from a somewhat more subtle set of empirically observed phenomena. The second key element, as defined by Porter (1980), of a firm's competitive strategy is the set of operating policies through which goals are achieved. More specifically, Porter (1996) suggests that strategy is the creation of a unique and valuable position involving a different set of activities from those pursued by competitors. Furthermore, strategy requires that the firm create a fit between its various activities. Fit is the unique way a firm's activities interact and reinforce one another. Thus, in contrast to the above literature, there is a complementary body of research that suggests that it is the differences in the competitive strategies of strategic alliance partners that produce synergistic effects. Schneider et al. (1997) suggest that differences with regard to competitive strategies enhance the ability of cooperative agreements to adapt to changes in the environment. Schneider and Bowen (1995) observe that differing perspectives on how to reach organizational goals may act to prevent the development of strategic myopia and inflexibility. Indeed, in a study of 78 international cooperation cases, van Oudenhoven and van der Zee (2002) found that with regard to corporate competitive strategy, strategic dissimilarity rather than similarity was critical to cooperation success.

Thus, sets of both strategic similarities and differences give rise to the important need for transparency in firms' competitive strategies. Similarity with regard to certain processes is necessary to build cooperation and trust-based relationships within strategic alliances. At the same time, distinctive/different competencies and resources are necessary in order for strategic alliances to build unique competitive advantages. 


\section{STRATEGIC TRANSPARENCY AND NATIONAL CULTURE}

As noted above, strategic transparency may have implications for alliance development and success. However, in a global alliance system, national cultural differences could impact perceptions of transparency and the willingness to disclose information. In examining cross-cultural differences, Hofstede $(1980,1984)$ and Hofstede and Bond (1988) identified five dimensions of national culture: individualism versus collectivism, power distance, masculinity versus femininity, uncertainty avoidance, and short-term versus long-term orientation. The dimension of individualism versus collectivism indicates the extent to which a society is a "loosely knit social framework" in which people are "supposed to take care of themselves and their immediate families only," instead of a "tightly knit social framework" in which people distinguish between in-groups and out-groups and expect their in-group to look after them in exchange for loyalty (Hofstede 1984, 83). The dimension of power distance indicates the extent to which a society accepts the fact that "power in institutions and organizations is distributed unequally" among individuals (Hofstede 1984, 83). The dimension of masculinity versus femininity indicates the extent to which the dominant values in society tend toward assertiveness and the acquisition of things, and away from concern for people and the quality of life. The dimension of uncertainty avoidance indicates the extent to which a society feels threatened by ambiguous situations and tries to avoid them by providing rules, believing in absolute truths, and refusing to tolerate deviation from the rule. Finally, the dimension of a short-term versus long- term orientation indicates the extent to which a society exhibits a pragmatic future-oriented perspective rather than a conventional historic or short-term point of view (Adler 1997).

In his study of the relationship between cultural/societal values and the development of accounting systems, attitudes toward financial management and disclosure, and the regulation of the accounting profession, Gray (1988) developed a framework of analysis using Hofstede's cultural dimensions. He identified four accounting value dimensions that influence a nation's financial reporting practices: professionalism versus statutory control, uniformity versus flexibility, conservatism versus optimism, and secrecy versus transparency. The fourth dimension, secrecy vs. transparency, is of particular interest to this study which explores competitive strategy disclosure. As defined by Gray $(1988,8)$, secrecy is a "preference for confidentiality and the restriction of disclosure of information about the business only to those who are closely involved with its management and financing as opposed to a more transparent, open and publicly accountable approach." He goes on to hypothesize that countries ranking higher in uncertainty avoidance and power distance will rank higher in terms of secrecy. Gray (1988) indicates that high uncertainty avoidance implies a preference for secrecy because of the need to restrict information disclosures in order to avoid conflict and competition. He also argues that societies ranking high on power distance prefer secrecy, or a lower level of disclosure, in order to preserve inequalities in power. Further, the lower a country ranks in terms of individualism "the more likely it is to rank high in terms of secrecy" (Gray 1988, 11). A collectivistic orientation, societies ranking lower in individualism, with a sense of responsibility to insiders as opposed to those external to the firm, would also be consistent with greater secrecy. With regard to masculinity, "more caring societies where more emphasis is given to the quality of life, people, and the environment, will tend to be more open" and transparent with regard to information (Gray 1988, 11). Therefore, societies with a masculine orientation would be more secretive than feminine cultures.

Competitive strategy disclosure is the most voluntary of the corporate disclosure categories. Therefore, the authors contend that cultural orientation, measured along Hofstede's dimensions, influences the level and intensity of strategy disclosure. National cultural differences have important implications for strategy disclosure in the global airline industry and are important in the context of alliance development. 


\section{THE USE OF CORPORATE ANNUAL REPORTS TO MEASURE TRANSPARENCY}

This research study uses corporate annual reports to assess the extent to which the members of the three major airline alliances disclose information relative to their strategy. Annual reports have been used extensively in research involving information disclosure (see Stanton and Stanton (2002) for an overview of the research perspectives used in corporate annual report studies). They are a medium through which companies communicate with their stakeholders and the public. However, corporate annual reports are more than formal documents used to convey mandatory corporate reporting requirements. As suggested by Hopwood $(1996,55)$, corporate annual reports construct a "particular visibility and meaning" as opposed to "what was there." Similarly, Hines $(1988,257)$ addresses the notion of communicating and constructing reality in annual report financial accounting disclosure: "We create a picture of an organization, or the 'economy,' whatever you like, and on the basis of that picture (not some underlying 'real' reality of which no one is aware), people think and act. And by responding to that picture of reality, they make it so; it becomes 'real in its consequences.' And what is more, when people respond to that picture, and the consequences occur, they see it as proof of our having correctly conveyed reality."

The use of annual reports for studies related specifically to disclosure has been well documented. Botosan $(1997,329)$ states that "although the annual report is only one means of corporate reporting, it should serve as a good proxy for the level of voluntary disclosure provided by a firm across all disclosure avenues." Lang and Lundholm (1993) note that annual report disclosure levels are positively correlated with the amount of disclosure provided via other media. Knutson $(1992,7)$ states that "at the top of every analyst's list (of financial reports used by analysts) is the annual report to shareholders. It is the major reporting document and every other financial report is in some respect subsidiary or supplementary to it." Patel and Dallas $(2002,6)$ suggest that the use of annual reports "facilitates analysis and comparison of companies around the globe."

\section{DATA COLLECTION}

An analysis of the intensity of strategy disclosure was conducted through the examination of the 2005 corporate annual reports filed by the full members of the three major airline alliances, Star, oneworld, and SkyTeam at that point in time. Two independent readers were utilized and their content analysis compared to reconcile any discrepancies. The initial content analysis yielded over $90 \%$ agreement between the readers. Any inconsistencies, as noted, were reconciled through discussion and further review of the annual reports. The Star Alliance members examined in the study included Air Canada, Air New Zealand, ANA, Austrian, LOT Polish Airlines, Lufthansa, SAS, Singapore Airlines, South African Airlines, Swiss, TAP Portugal, Thai, United, U.S. Airways, and Varig. It should be noted that annual reports for two members of the Star Alliance, Asiana and BMI, were not available for 2005 or the prior year 2004. These companies were, therefore, excluded from the research. The members of the oneworld Alliance included in the study consisted of Aer Lingus, American Airlines, British Airways, Cathay Pacific, Finnair, Iberia, LAN, and Qantas. The SkyTeam Alliance members studied included Aeroflot, Aero Mexico, Air France, Alitalia, Continental, Czech Airlines, Delta, Korean Air, and Northwest Airlines. It should be noted that the 2005 annual reports were not available for Varig and Swiss Air International. However, the authors had access to the 2004 annual reports and thus these were used in the analysis. The 32 airlines included in this study are listed in Table 1, along with an indication of their respective alliance membership. 
Table 1: Airline Alliances Members

\begin{tabular}{|c|c|}
\hline Airline & Alliance \\
\hline Aeroflot & SkyTeam \\
\hline Aer Lingus & oneworld \\
\hline Aeromexico & SkyTeam \\
\hline Air Canada & Star \\
\hline Air France & SkyTeam \\
\hline Air New Zealand & Star \\
\hline Alitalia & SkyTeam \\
\hline All Nippon Airways & Star \\
\hline American Airlines & oneworld \\
\hline Austrian Airlines & Star \\
\hline British Airways & oneworld \\
\hline Cathay Pacific Airways & oneworld \\
\hline Continental Airlines & SkyTeam \\
\hline Czech Airlines & SkyTeam \\
\hline Delta Airlines & SkyTeam \\
\hline Finnair & oneworld \\
\hline Iberia Airlines & oneworld \\
\hline Korean Airlines & SkyTeam \\
\hline LAN & oneworld \\
\hline LOT Airlines & Star \\
\hline Lufthansa & Star \\
\hline Northwest Airlines & SkyTeam \\
\hline Qantas Airways & oneworld \\
\hline Scandinavian Airlines & Star \\
\hline Singapore Airlines & Star \\
\hline South African Airways & Star \\
\hline Swiss International Airlines & Star \\
\hline TAP Air Portugal & Star \\
\hline Thai Airways & Star \\
\hline United Airlines & Star \\
\hline US Airways & Star \\
\hline Varig & Star \\
\hline
\end{tabular}

A template was developed to measure the degree of disclosure of competitive strategy by airlines in each of the three global strategic alliances. This template, an adaptation of the Santema and van Oijen (2005) model, included the following items:

\section{Business Definition:}

a. Describe the business of the corporation/airline.

b. Scope of the business: geographic (number and identification of destinations/locations), customer markets, long haul/short haul, etc.

c. Address the question: Who do we serve and how do we serve them?

2. Goals (Qualitative) and Vision: For example "become a leading airline"; "become number one in every market in which we fly"; "become the number one European carrier." 
3. Objectives: Describe what is to be accomplished and when - specification of quantifiable objectives with target date for achievement.

4. Internal Strengths: Identification of strategically critical organizational assets (tangible or intangible), core and distinctive competencies, core capabilities.

5. Internal Weaknesses: Identification of resource gaps, core deficiencies.

6. Opportunities: Identification of external factors/forces/trends (competitive, economic, political/legal, social/cultural, technological) that pose opportunities.

7. Threats: Identification of external factors/forces/trends (competitive, economic, political/ legal, social/cultural, technological) that pose threats.

8. Strategic matching of internal strengths and weaknesses and external opportunities and threats. Indicated how organizational strengths could be used to take advantage of external opportunities and/or used to reduce the airline's vulnerability to external threats. Indicated how organizational weaknesses inhibit the airline's ability to take advantage of opportunities and/or increased its vulnerability to external threats and how such weaknesses could be overcome.

9. Corporate Level Strategy: Identification of the industries/businesses in which the company is/should be involved; Discussion of the directional strategy with respect to growth (growth, stability, retrenchment); Discussion of strategies to manage across units (synergies).

10. Business Level Strategies: How is/should the company compete? (Porter (1980): Low cost position, differentiation, niche/focus).

11. Monitoring/Control/Benchmarking: Indication of efforts to monitor and benchmark performance areas - identification of specific initiatives to collect data and measure performance.

12. Examples of Realized Goals/Strategies: Concrete examples of the achievement of previous year's goals and objectives and the tactical strategies that contributed to goal achievement.

13. Examples of Projected Goals/Strategies: Concrete examples of strategies to achieve next year's goals and objectives - specific tactical strategies.

All of the narrative sections of the annual reports of each airline were read and assessed to determine the relative level of disclosure for each of the 13 strategy items. The transparency of each item was evaluated on a scale of no disclosure, minimum level of disclosure for the sample, average level of disclosure for the sample, and above average level of disclosure for the sample. Numerical scores of zero, one, two, and three were assigned accordingly. A total score was calculated across all 13 categories for each airline.

Table 2 displays Hofstede's (1980) indices, scores attributable to each airline based on national culture, for each of four dimensions: uncertainty avoidance (UA), power distance (PD), individualism (IND), and masculinity (MAS). High values for each of these four indices would indicate a national culture characterized by high uncertainty avoidance, high power distance, strong individualistic qualities, and a strong masculine orientation. It should be noted that scores for the fifth dimension of short-term versus long-term orientation were not available, as the original study by Hofstede and Bond (1988) that examined this dimension provided scores for only a very small subset of the airlines in this study.

The total strategy disclosure score for each airline is also displayed in Table 2. As previously noted, 13 strategy categories were evaluated and rated with scores ranging from 0 to 3 based on the degree of transparency. Therefore, the lowest possible strategy disclosure score for an airline is 0 and the highest score is 39 . Scores above a 30 indicate significant competitive strategy disclosure and transparency. 
Table 2: Disclosure and Cross-Cultural Factor Ratings*

Uncertainty Avoidance, Power Distance, Individualism, Masculinity

\begin{tabular}{|c|c|c|c|c|c|}
\hline Airline & UA & PD & IND & MAS & $\begin{array}{l}\text { DISCL. } \\
\text { SCORE }\end{array}$ \\
\hline \multicolumn{6}{|l|}{ ONEWORLD } \\
\hline Aer Lingus & 35 & 28 & 70 & 68 & 16 \\
\hline American Airlines & 46 & 40 & 91 & 62 & 24 \\
\hline British Airways & 35 & 35 & 89 & 66 & 34 \\
\hline Cathay Pacific Airways & 29 & 68 & 25 & 57 & 17 \\
\hline Finnair & 59 & 33 & 63 & 26 & 28 \\
\hline Iberia Airlines & 86 & 57 & 51 & 42 & 27 \\
\hline LAN & 86 & 63 & 23 & 28 & 23 \\
\hline Qantas Airways & 51 & 36 & 90 & 61 & 30 \\
\hline \multicolumn{6}{|l|}{ SKYTEAM } \\
\hline Aeroflot & 95 & 93 & 39 & 36 & 21 \\
\hline Aeromexico & 82 & 81 & 30 & 69 & 23 \\
\hline Air France & 86 & 68 & 71 & 43 & 31 \\
\hline Alitalia & 75 & 50 & 76 & 70 & 27 \\
\hline Continental Airlines & 46 & 40 & 91 & 62 & 26 \\
\hline Czech Airlines & 74 & 57 & 58 & 57 & 30 \\
\hline Delta Airlines & 46 & 40 & 91 & 62 & 30 \\
\hline Korean Airlines & 85 & 60 & 18 & 39 & 22 \\
\hline Northwest Airlines & 46 & 40 & 91 & 62 & 30 \\
\hline \multicolumn{6}{|l|}{ STAR } \\
\hline Air Canada & 48 & 39 & 80 & 52 & 26 \\
\hline Air New Zealand & 49 & 22 & 79 & 58 & 36 \\
\hline All Nippon Airways & 92 & 54 & 46 & 95 & 28 \\
\hline Austrian Airlines & 70 & 11 & 55 & 79 & 37 \\
\hline LOT Airlines & 93 & 68 & 60 & 64 & 23 \\
\hline Lufthansa & 65 & 35 & 67 & 66 & 34 \\
\hline Scandinavian Airlines & 34 & 27 & 71 & 9 & 32 \\
\hline Singapore Airlines & 8 & 74 & 20 & 48 & 18 \\
\hline South African Airways & 49 & 49 & 65 & 63 & 25 \\
\hline Swiss International Airlines & 58 & 34 & 68 & 70 & 27 \\
\hline TAP Air Portugal & 104 & 63 & 27 & 31 & 24 \\
\hline Thai Airways & 64 & 64 & 20 & 34 & 22 \\
\hline United Airlines & 46 & 40 & 91 & 62 & 25 \\
\hline US Airways & 46 & 40 & 91 & 62 & 29 \\
\hline Varig & 76 & 69 & 38 & 49 & 11 \\
\hline
\end{tabular}

* Hofstede (1980) 


\section{RESULTS AND ANALYSIS}

As seen in Table 2, there are differences between the airlines relative to the level of competitive strategy disclosure. The disclosure scores ranged from a low of 11 (Varig) to a high of 37 (Austrian Airlines). The median score for all of the airlines was 26.5. In terms of differences in the intensity of competitive strategy disclosure between the alliances, alliance membership does not appear to have an impact on the level of disclosure. The differences of the mean disclosure scores among alliances were not statistically significant.

Within each alliance, individual airline disclosure scores differed and the importance of national culture is apparent. The relationship between Hofstede's cross-cultural factors (1980) and competitive strategy disclosure was examined by dividing the sample into those airlines that were above the median in competitive strategy disclosure (as measured by the total score) and those that were below the median. A test of differences in means was done using the non-parametric Wilcoxon test (see Table 3A). The software utilized is the NPAR1WAY procedure in SAS (2002). This test was performed with and without the U.S. airlines. Annual reports of U.S. airlines include the Form $10 \mathrm{~K}$ in addition to other material. Thus, these airlines were held out of the sample when the test was performed a second time to test for any bias because of this difference in annual report format (See Table 3B).

Table 3A: Non-parametric Test of Means (Wilcoxon) of Cross-Cultural Factors Above Median versus Below Median Disclosure - Full Sample

\begin{tabular}{|l|c|c|c|c|}
\hline \multicolumn{4}{|c}{ UA } & \multicolumn{2}{c|}{ PD } & IND & MAS \\
\hline Above Median & 60.75 & $39.94 * * *$ & $72.31 * *$ & 58.00 \\
\hline Below Median & 62.00 & $58.69 * * *$ & $49.25 * *$ & 51.50 \\
\hline
\end{tabular}

$* * *=$ Statistically significant at $1 \%$ level

$* *=$ Statistically significant at $5 \%$ level

Table 3B: Non-parametric Test of Means (Wilcoxon) of Cross-Cultural Factors Above Median versus Below Median Disclosure - U.S. Airlines Excluded

\begin{tabular}{|c|c|c|c|c|}
\hline & UA & PD & IND & MAS \\
\hline Above Median & 64.15 & $39.92 * * *$ & $68.00 * * *$ & 57.08 \\
\hline Below Median & 65.69 & $63.00 * * *$ & $39.62 * * *$ & 49.08 \\
\hline
\end{tabular}

$* * *=$ Statistically significant at $1 \%$ level

The findings indicate that there is a correlation between national culture and strategy information disclosure. The results displayed in Table 3A show that the intensity of competitive strategy disclosure is negatively correlated with power distance, with statistical significance at a $1 \%$ level. Therefore, airlines from societies that are more accepting of power inequalities disclosed less information relative to organizational strategy. This supports Gray's (1988) hypothesis that countries ranking higher in power distance will rank higher in secrecy. Reporting in low power distance cultures tends to be more comprehensive than in high power distance cultures (Hussein 1996). In this study, Austrian Airlines, for example, had the lowest power distance rating in the sample and scored the highest on level of strategy disclosure.

There is a positive correlation between the intensity of disclosure and individualism at a $5 \%$ level of statistical significance. Airlines from countries that ranked higher in individualism ranked higher in competitive strategy disclosure. The demand for accountability may be greater in individualist societies and, therefore, the level of disclosure may be greater than that of collectivist societies (Santema and van Oijen 2005). This finding also supports Gray's hypothesis that countries ranking lower in terms of individualism rank higher in terms of secrecy and, therefore, lower in disclosure. 
Societies favoring a collectivist orientation, by distinguishing between in-groups and out-groups, reveal less information to external constituencies and the public. The relationship between strategy disclosure and masculinity was not found to be statistically significant. Similarly, the relationship between strategy disclosure and uncertainty avoidance was not statistically significant. In this case, however, the findings indicate that the direction of the relationship supports Gray's (1988) hypothesis that countries ranking higher in uncertainty avoidance will rank higher in secrecy.

The results presented in Table 3B, which excludes the U.S. airlines whose annual reports include the Form 10K, support the findings discussed above. The level of competitive strategy disclosure is negatively correlated with power distance, with statistical significance at a $1 \%$ level. The positive correlation between the intensity of disclosure and individualism actually improved to a $1 \%$ level when the U.S. airlines were excluded. As in Table 3A, the relationships between strategy disclosure and masculinity and strategy disclosure and uncertainty avoidance were not found to be statistically significant. Again, the direction of the relationship between strategy disclosure and uncertainty avoidance supports Gray's (1988) hypothesis. It should be noted that the differences in cross-cultural factor ratings between the three airline alliances were not statistically significant.

Table 4 presents the Pearson correlation coefficients for the disclosure score variable and each of Hofstede's four cultural dimension variables. The statistically significant correlations between the disclosure score variables and those for power distance and individualism are consistent with the results in Table 3A and Table 3B. However, there is also information in Table 4 which yields an even richer story as to how the four dimension variables interact and reinforce each other. In addition to ranking national cultures along the four dimensions of uncertainty avoidance, power distance, individualism, and masculinity, Hofstede (1991) also considered pairings of these dimensions to further describe particular countries, based on the pair-wise inter-correlations between the four dimension variables. He found that nations like Thailand, Korea, Singapore, Chile, Portugal, Japan, Brazil, Hong Kong, and Mexico were characterized as large power distance - collectivist. These are the home countries of Thai Airways, Korean Airlines, Singapore Airlines, LAN, Tap Air Portugal, All Nippon Airways, Varig, Cathay Pacific Airways, and Aeromexico, which is reflected in the statistically significant negative correlation (-0.67 in Table 4) between power distance and individualism in this study's sample.

Nations like South Africa, Austria, Germany, Switzerland, Ireland, France, Italy, Canada, New Zealand, Australia, Great Britain, and the United States were characterized as individualist masculine. These are the home countries of South African Airways, Austrian Airlines, Lufthansa, Swiss International Airlines, Aer Lingus, Air France, Alitalia, Air Canada, Air New Zealand, Qantas Airways, British Airways, American Airlines, Continental Airlines, Delta Airlines, Northwest Airlines, United Airlines, and US Airways, which is reflected in the statistically significant positive correlation (0.35 in Table 4) between individualism and masculinity in this study's sample.

Nations like Korea, Thailand, Chile, Mexico, Portugal, Brazil, Spain, and Japan were characterized as strong uncertainty avoidance - collectivist. These are the home countries of Korean Airlines, Thai Airways, LAN, Aeromexico, Tap Air Portugal, Varig, Iberia Airlines, and All Nippon Airways, which is reflected in the statistically significant negative correlation ( -0.39 in Table 4) between uncertainty avoidance and individualism in this study's sample.

Finally, nations like Thailand, Italy, Brazil, Chile, Korea, Mexico, Spain, France, Japan, and Portugal were characterized as large power distance - strong uncertainty avoidance. These are the home countries of Thai Airways, Alitalia, Varig, Korean Airlines, Aeromexico, Iberia Airlines, Air France, All Nippon Airways, and TAP Air Portugal, which is reflected in the statistically significant positive correlation ( 0.45 in Table 4$)$ between power distance and uncertainty avoidance in this study's sample.

The correlation between masculinity and uncertainty avoidance and masculinity and power distance were not found to be statistically significant in this sample. 
Table 4: Pearson Correlation Coefficients / Hofstede's Dimensions and Disclosure Score Prob $>|\mathbf{r}|$ under $\mathbf{H}_{0}:$ Rho $=0$

\begin{tabular}{|c|c|c|c|c|c|}
\hline 7 & DSCORE & UA & PD & IND & MAS \\
\hline DSCORE & 1.00000 & -0.02125 & $\begin{array}{c}-0.61832 \\
* * *\end{array}$ & $\begin{array}{c}0.53665 \\
* * *\end{array}$ & 0.17556 \\
\hline UA & & 1.00000 & $\begin{array}{c}0.44755 \\
* * *\end{array}$ & $\begin{array}{c}-0.39406 \\
* * \\
\end{array}$ & -0.08344 \\
\hline PD & & & 1.00000 & $\begin{array}{c}-0.66625 \\
* * *\end{array}$ & -0.25145 \\
\hline IND & & & & 1.00000 & $\begin{array}{c}0.34701 \\
* *\end{array}$ \\
\hline MAS & & & & & 1.00000 \\
\hline
\end{tabular}

$* * *=$ Statistically significant at $1 \%$ level

$* *=$ Statistically significant at $5 \%$ level

The relationship between these dimensional pairings or subgroups and the level of competitive strategy disclosure was examined using the Tukey-Kramer method (Tukey 1953, Kramer 1956). In this case, testing differences in the means was complicated by the fact that the sub-samples were of unequal size. The original Tukey test (1952) was designed specifically for pair wise comparisons based on the studentized range ratio (see formula below) and controls the maximum experimentwise error rate (MEER) when the sample sizes are equal. The sample sizes in this study were not equal and, therefore, the unequal cell sizes required that an extension of the test proposed by Tukey $(1952,1953)$ be used. Tukey (1953) and Kramer (1956) independently proposed a modification for unequal cell sizes and it is the Tukey-Kramer method that was used in this study. Hayter (1984) provided proof that the Tukey-Kramer procedure controls the MEER and it has also fared well in Monte Carlo studies (Dunnett 1980).

Specifically, for two groups $y_{i}$ and $y_{j}$, with $n_{i}$ and $n_{j}$ observations in each group respectively and $s$ being the root mean square error based on $v$ degrees of freedom, their means $\overline{y_{i}}$ and $\overline{y_{j}}$ are considered significantly different by the Tukey-Kramer criterion if:

$$
\left|\bar{y}_{i}-\bar{y}_{j}\right| / s \sqrt{\left(1 / n_{i}+1 / n_{j}\right) / 2} \geq q(\alpha ; \kappa, v)
$$

where $q(\alpha ; \kappa, v)$ is the $\alpha$-level critical value of a studentized range distribution of $\kappa$ independent normal random variables with $v$ degrees of freedom. The software utilized is the GLM (General Linear Model) procedure in SAS (2002), which calculates significance for the Tukey-Kramer statistic at the $5 \%$ level.

As can be seen in Table 5, airlines whose national culture was classified as either large power distance - collectivist or uncertainty avoidance - collectivist had disclosure scores which, on average, were statistically significantly less than those of the other airlines in the sample. Airlines whose national culture was classified as individualist - masculine had disclosure scores, which on average, were statistically significantly greater than those of the other airlines in the sample. No statistically significant difference was found for airlines whose national culture was classified as power distance - strong uncertainty avoidance and the other airlines in the sample. 
Table 5: Non-Parametric Test of Means (Tukey-Kramer)

Disclosure Differences by Large Power Distance - Collectivist, Individualist -

Masculine, Uncertainty Avoidance - Collectivist, Power Distance - Strong Uncertainty Avoidance Subgroups

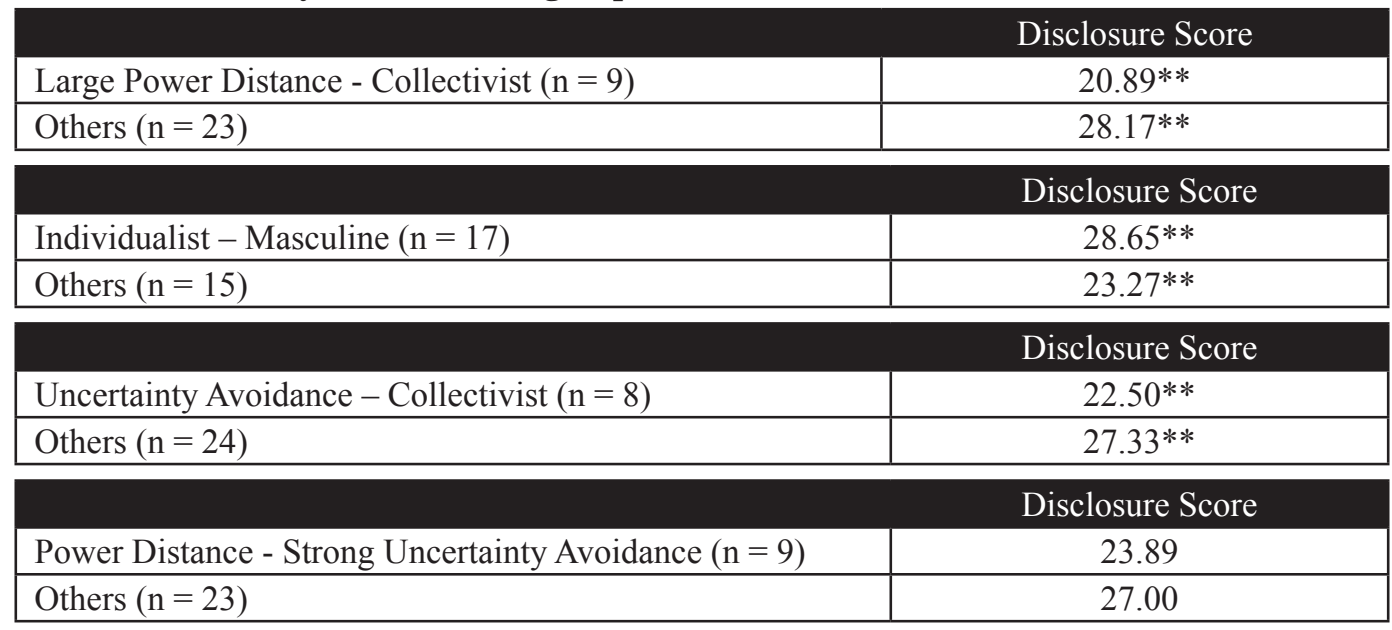

$* *=$ Statistically significant at $5 \%$ level

\section{CONCLUSION}

The results of the study indicate that there is a discernable and significant relationship between national culture and the intensity of corporate strategy disclosure in the airline industry. As compared to financial and governance information, competitive strategy disclosure is the most voluntary with little in the way of common disclosure standards. National values and cultural differences, therefore, may have a more profound impact on the disclosure of strategy information. The practical implications for managers in the airline industry include the recognition that members of the same alliance may not view the need to disclose information from the same cultural lenses and, therefore, voluntary disclosure will vary across companies. Further, the results of the study suggest that membership in an alliance does not guarantee commonality in the level of information sharing, specifically strategic information.

As noted earlier, it has been observed that the global airline strategic alliances have not moved beyond the initial phase, as described by Doganis (2001), that is oriented toward revenue generation through network expansion and joint marketing (Cools and Roos 2005). National cultural differences as they relate to information disclosure may play a role in inhibiting the progress toward the subsequent phases. The potential benefits and synergies that can be achieved through the alliance systems may be more readily apparent and realized with increased competitive strategy transparency.

Future studies that examine the relationship between corporate transparency and alliance membership stability, relationship development, and economic benefits/success may provide greater insight into alliance development barriers. Longitudinal studies focusing on the intensity of information disclosure and the success of alliance systems over time may provide airline managers with practical insight into the implications of information asymmetry on the long-term effectiveness of alliance relationships. In this regard, it is interesting to note that Varig, whose disclosure score of 11 was the lowest in the sample, has subsequently left the Star Alliance. In addition, future studies that integrate multiple dimensions of information disclosure including financial, governance, and strategic information, may provide a more complete understanding of differences in corporate transparency within and among the airline alliances. 


\section{References}

Adler, N. International Dimensions of Organizational Behavior. South-Western College Publishing, Cincinnati, Ohio, 1997.

Botosan, C. "Disclosure Level and the Cost of Capital." The Accounting Review 72(3), (1997): 323-347.

Bushman, R., J. Piotroski, and A. Smith. "What Determines Corporate Transparency?” Journal of Accounting Research 42(2), (2004): 207- 252.

Cools, K. and A. Roos. The Role of Alliances in Corporate Strategy. The Boston Consulting Group, Boston, Mass., 2005.

Credit Lyonnais Securities Asia. Corporate Governance in Emerging Market: Saints and Sinners, Who's Got Religion? Credit Lyonnais Securities, New York, New York, 2001. Available at: http:// www.worldbank.org/wbi/banking/finsecpolicy/domestic2003/readings.html

Doganis, R. The Airline Business in the 21 ${ }^{\text {st }}$ Century. Routledge, New York, N.Y., 2001.

Doidge, C., A. Karolyi, and R. Stulz. "Why Do Countries Matter So Much for Corporate Governance?" Journal of Financial Economics forthcoming.

Dunnett, C. "Pairwise Multiple Comparisons in the Homogeneous Variance, Unequal Sample Size Case." Journal of the American Statistical Association 75(372), (1980): 789-795.

Giapponi, C. and C. Scheraga. "Cross-Cultural Factors and Corporate Governance Transparency in Global Airline Strategic Alliances." Journal of the Transportation Research Forum 46(2), (2007):101-122.

Gray, S. "Towards a Theory of Cultural Influence on the Development of Accounting Systems Internationally." Abacus 24(1), (1988): 1-15.

Hayter, A. "A Proof of the Conjecture that the Tukey-Kramer Method is Conservative." Annals of Statistics 12(1), (1984): 61-75.

Hines, R. "Financial Accounting: In Communicating Reality, We Construct Reality." Accounting Organizations and Society 13(3), (1988): 251-261.

Hofstede, G. Culture’s Consequences. Sage Publications, Beverly Hills, California, 1980.

Hofstede, G. "Cultural Dimensions in Management and Planning." Asia Pacific Journal of Management 1(2), (1984): 81-99.

Hofstede, G. Cultures and Organizations: Software of the Mind. McGraw-Hill Book Company, London, United Kingdom, 1991.

Hofstede, G. and M. Bond. "The Confucius Connection: From Cultural Roots to Economic Growth." Organizational Dynamics 16(4), (1988): 4-21.

Institutional Shareholder Services. ISS Corporate Governance Quotient. ISS, Rockville, MD, 2003. Available at http://www.isscgq.com/RatingCriteria.htm and www.issproxy.com

Hopwood, A. “Introduction.” Accounting, Organizations and Society 21(1), (1996): 55-56. 
Hussein, M. "A Comparative Study of Cultural Influences on Reporting in the USA and the Netherlands." The International Journal of Accounting 31(1), (1996): 95-120.

Knutson, P. "Financial Reporting in the 1990s and Beyond: A Position Paper of the Association for Investment Management and Research.” Working Paper, University of Pennsylvania, 1992.

Koza, M. and A. Lewin. "The Co-Evolution of Strategic Alliances." Organization Science 9(3), (1998): 255-264.

Kramer, C. "Extension of Multiple Range Tests to Group Means with Unequal Numbers of Replications." Biometrics 12(3), (1956): 307-310.

Lang, M. and R. Lundholm. "Cross-Sectional Determinants of Analysts Ratings of Corporate Disclosures." Journal of Accounting Research 31(2), (1993): 246-271.

Lewis, J. Partnerships for Profit: Structuring and Managing Strategic Alliances. The Free Press, New York, New York, 1990.

Meek, G., C. Roberts, and S. Gray. "Factors Influencing Voluntary Annual Report Disclosures by U.S., U.K. and Continental European Multinational Corporations." Journal of International Business Studies 26(3), (1995): 555-572.

Patel, S. and G. Dallas. Transparency and Disclosure: Overview of Methodology and Study Results. Standard \& Poor's, New York, N.Y., 2002.

Porter, M. Competitive Strategy. The Free Press, New York, N.Y., 1980.

Porter, M. The Competitive Advantage of Nations. The Free Press, New York, N.Y., 1990.

Porter, M. “What Is Strategy?” Harvard Business Review 74(6), (1996): 61-79.

Santema S. and J. van de Rijt. "Strategy Disclosure in Dutch Annual Reports.” European Management Journal 19(1), (2001): 101-108.

Santema, S. and A. van Oijen. "Strategy Disclosure in Annual Reports Across Europe: A Study on Differences Between Five Countries.” European Business Review 17(4), (2005): 352-366.

SAS Institute, Inc. SAS/STAT User's Guide, Version 8. Cary, North Carolina, 2002.

Saxton, T. "The Effects of Partner and Relationship Characteristics on Alliance Outcomes." Academy of Management Journal 40(2), (1997): 443- 460.

Schneider, B. and D. Bowen. Winning the Service Game. Harvard Business School Press, Boston, Mass., 1995.

Schneider, B., A. Kristof-Brown, H. Goldstein, and D. Smith. "What Is Thing Called Fit?" N. Anderson and P. Herriot eds. International Handbook of Selection Assessment. Chichester, United Kingdom: Wiley (1997): 393-412.

Spekman, R., T. Forbes III, L. Isabella, and T. MacAvoy. “Alliance Management: A View from the Past and a Look to the Future.” The Journal of Management Studies 35(6), (1998): 747-772.

Standard \& Poors. Standard \& Poors Corporate Governance Scores and Evaluations: Criteria, Methodology and Definitions. Standard and Poors Governance Services, New York, N.Y., 2004. 
Global Airline Strategic Alliances

Stanton, P. and J. Stanton. “Corporate Annual Reports: Research Perspectives Used.” Accounting, Auditing and Accountability Journal 15(4), (2002): 478-500.

Tukey, J. “Allowances for Various Types of Error Rates." Unpublished IMS Address, Chicago, Ill., 1952.

Tukey, J. “The Problem of Multiple Comparisons.” Unpublished Manuscript, 1953.

Van Oudenhoven, J. and K. van der Zee. "Successful International Cooperation: The Influence of Cultural Similarity, Strategic Differences, and International Experience." Applied Psychology 51(4), (2002): 633-653.

Whipple, J. and R. Frankel. "Strategic Alliance Success Factors." Journal of Supply Chain Management 36(3), (2000): 21-28.

Catherine C. Giapponi is assistant professor of Business Management. Her fields of research and teaching include business strategy, global strategic management, corporate governance and ethics in business decision-making. She has published articles in the North East Journal of Legal Studies, International Journal of Risk Assessment and Management, and the Journal of Business Ethics.

Giapponi received her Sc.D in management from the University of New Haven, an M.B.A. from the University of Connecticut, and a B.A. from Providence College.

CarlA. Scheraga is professor of Business Strategy and Technology Management. His fields of research and teaching include transportation and international logistics, global strategic management, crosscultural management, and the management of technology and innovation. Scheraga has published numerous articles in Transportation Research Series A, Journal of Transportation Management, Transportation Journal, Journal of the Transportation Research Forum, Journal of Public Policy and Marketing, Technology in Society: An International Journal, Journal of Banking and Finance, Global Business and Finance Review, Journal of Investing, Management International Review, International Journal of Advertising, and International Review of Economics and Finance. He also has published chapters in such volumes as Japanese Direct Investment in the United States: Trends, Developments and Issues and International Financial Market Integration. As a co-author, he has received the Transportation Research Forum Outstanding Research Paper Award in 1998 and the Aviation Research Paper Award in 1999.

Scheraga received his Ph.D. in economics from the University of Connecticut, an M.A. in economics, and a Sc.B in mathematics and engineering from Brown University. 